\title{
An Gigantic Exhibition on Paul Gauguin (1848-1903) and His Enigmatic Work Has Recently Opened at the Grand Palais in Paris. Its Title is Equally Grand- Scale and Promising: "Gauguin, L'alchimiste" - "The Alchemist"
}

\author{
Flemming Friborg* \\ Department of Arts \& Cultural Studies, France, Europe
}

Submission: November 13, 2017; Published: March 26, 2018

*Corresponding author: Flemming Friborg, Dept. of Arts \& Cultural Studies France, Europe, Email: flemming.friborg@zoho.com

\section{Opinion}

Alchemistis a beautiful and dangerous word. We have come to view alchemy as a magical lore and pseudo-scientific practice, with the one goal of forging gold out of base elements (as basic as water, earth, fire and air) - by chemical, mechanical and/or incantational means craft noble metalout of simple matter. But alchemy is also an early attempt at divining the essence of all things, the whys, hows and wherefores of existence, and in its golden age (sorry) from the late Middle Ages until c. 1700, when it was killed off by the Enlightenment [1], the practitioners of alchemy danced on a razor's edge somewhere between science and superstition, art and heresy. With a mustering of almost 300 of Gauguin's works, crossing all media and motifs of his oeuvre, the stage seems set in Paris for a re-evaluation of his art as alchemistic: a quest marked by the flagrant and ruthless use of everything around him, all of it poured into an artistic crucible in order to be transformed into gold.

The project "Gauguin as Alchemist" unites the forces of two of the world's richest Gauguin collections, those of the Art Institute of Chicago and the Paris Musee d'Orsay respectively, and has been underway since 2011. Paris is second venue for once, after a somewhat different version was shown in Chicago from June 25 through September 10. In this blockbuster show visitors to the French capital may wallow in the "complete" Gauguin, and although the exhibition is not the first to review his work in all genres and media (as claimed in the catalogue foreword, and then disclaimed in its very first essay) it may well be the broadest and most sweeping. Ventures of this sort are like comets, they appear but rarely. Last time Gauguin was regaled with attention on this scale was at the National Gallery Washington in 1988.

Not long after Gauguin's early death, some found that one of the artist's greatest mistakes was that he didn't pay closer attention to the opinions of the critic Felix Feneon (1861-1941) In January 1888, Feneon wrote a short but succinct review in the periodical La revue independent of what was currently on show at the art dealership of messrs. Boussod, Valadon \& Cie. After damning Gauguin's Impressionist canvases with faint praise, he observed:

“(...) these proud paintings would be the acme of mr Paul Gauguin's work if this grinch of an artist was not first and foremost a potter. He loves the humble, ominous and hard clay; deranged faces, snubnosed, with swollen brows and small, slanted eyes" [2].

The critic had put his finger on the crux of the matter. The by then 40-year old artist had been a late starter, lagging after the main, first-wave Impressionists (Monet, Degas and Pissarro) in both technique and originality. What was worse, he knew so himself. Now, two years after Georges Seurat (1861-91) had shown his Neo-Impressionist works made up of myriad dots (taches) of pure colour and had thus struck a whole new and more 'scientific' course for painting, Gauguin felt the pressure. Constant change and radical individual originality had become buzzwords of the day, and his paintings were too bland to stand out sufficiently in the crowd of nouvelle peinture artists. Seurat's work may have been in the positivist spirit of the day, based as it was upon optics and perceptional philosophy, but it was also intensely sensuous - like dreams analytically invoked and arranged in pure colours against each other. Gauguin's answer was a wild gamble for STYLE above all, a maneouver which was aimed at turning focus away from technical virtuosity. Gauguin was wary of the inherent superficiality of simply representing nature which he felt had lurked in Impressionism from the onset.

By November 1888, hedeclares that he will henceforth abstain from the whole game of representational one upmanship. 


\section{Global Journal of Archaeology \& Anthropology}

In a carefully conceived letter to Dujardin, editor of La revue independante, the same in which Feneon starred, Gauguin responds to an invitation to show his work at the premises:

"Having felt for 3 years that my powers as an artist were utterly inadequate for the modern forms of progress introduced among the Impressionist artists, so quickly replaced by the NeoImpressionists, I decided to work in isolation, without being promoted by any group. My studies made in the tropics are inadequate as precise renderings of nature, and I believe that the Revue Independante would be powerless to give them the brightness and luminosity they lack" [3].

Notwithstanding that Gauguin found the office rooms of the Revue utterly unsuited for his (or anyone's) paintings, he was also keenly aware that if he exhibited there he would be measured against the most recent exhibition of the latest works by, among others, Paul Signac - fifteen years his junior and already an up-and-coming exponent of Seurat's new 'optically enhanced' style [4]. Competition was fierce, and Gauguin was not usually one to shy away from a good fight, but just around this time, he was striking a new course, with his ceramics as the most recent - and perhaps boldest - venture. Here, something decidedly un-Impressionistic was stirring, and this was what piqued Feneon in spite of his obvious dislike of Gauguin as both a person and an artist. But this critic was an exception, and in general, Gauguin's ceramics were neither understood nor appreciated by his contemporaries.

Even now, the ceramic works seem unwieldy - and very, very modern - at first glance. The clay might certainly be viewed as the mirror in which all of Gauguin's work is, if not reflected, then prismatically refracted. The epithet of the "humble yet honest" material is idiomatically apt: the strangely distorted shapes and wide formal variety of Gauguin's ceramics lend themselves perfectly to his ambiguous ambitions - a constant and ever radical trial-and-error search or quest for something raw, primitive and counter-civilisational.

Such a focus may well have been the conceptual impetus of this grand-scale exhibition, which in Paris has been boosted by adding even more works to the already impressive bulk of the catalogue."Gauguin l'alchimiste" is a massive undertaking; having originated, the foreword informs us, simultaneously in Chicago and Paris, the concept was subjected to pooled resources in order for the two institutions not to obstruct each other and to the benefit of the public at both venues. Being too large for the Orsay rooms, it was decided to have Grand Palais host it, as often with blockbuster exhibitions in the French capital.

Such is the name of the game, and this fact need not in itself be a problem. But the understandable eagerness to present this 'new' take on Gauguin has sparked a desire to broaden the sweep, even though this is exactly what the planners insist upon wanting to avoid. The sheer marketing force of this Grand Display seriously risks trumping the conceptual base of the show. That is a shame, because the original concept is really worth exploring. In Paris, the ceramics do feature prominently and in great numbers - but so does everything else in Gauguin's oeuvre, to an extent which is on the verge of making the exhibition appear inflated rather than a tour de force. It runs the risk of obscuring the boldest elements of the whole venture, the idea of putting the ceramics (along with key graphic works, such as some of the zincographies from the Suite Volpini (1889) and some late Polynesian master-prints) centre stage. The rich ore in these sections of Gauguin's work is thus not mined deeply enough.

But no matter: as there have been other exhibitional and scholarly essays along if not the exact same, then similar lines of enquiry of late, Gauguin research seems set on a promising course. The novel way of thinking about Gauguin as a "bricoleur" (his own word, by the way), a term which in French implies equal measures of juxtaposing, fusing or forcing disparate elements together to make art, seems practice able. This exhibition and its catalogue strikes that course, and luckily goes as far as including the secondary definition of bricolage as dappling or hackwork a much-needed breath of irreverence in the review of an artist who frequently and admittedly stole from the work of his peers like a magpie and cared not much. Gauguin's attitude to the 'sources' around him is also an area which may never be fully exhausted by scholarship. His use of everything from photos of Javanese temples and dancers, Egyptian or Persian reliefs, to Norwegian drinking vessels, literary texts and tribal lore in his work daunts any researcher by its haphazard jumble and lack of linear progress. The Polynesian adventure 1891-1903 is not even exhausted yet, in spite of numberless exhibitions on this theme.

In its frequent and prominent use of the concept "Maori" as a collective term, the Chicago/Paris catalogue may be on a par with the artist himself, who seldom bothered to check his anthropological facts. He alternately writes "Maori" and "Maohi", which is less than precise (Maori is usually employed only by the peoples of New Zealand and the Cook Islands to signify themselves, not as a general term for the Polynesian populace). Here, although refreshingly non-PC, it is a little bit like using "Africans" as a common denominator for the entire population of that continent; the use of "Maori" in this way is at best partisanship of a view of Gauguin as a bit of a Western oaf who didn't know better, but if that's the point intended it might have been specifically mentioned or explained.

Gloria Groom's fine essay “Avant et Après: All This and All That" (pp.18-25) which initiates the beautifully produced catalogue's essay section is an overview of some of the most important art historical exploits into Gauguin as an artist and 'savage' over the past twenty years. The - rather variedly biased - viewpoints pro or con Gauguin as, respectively, a Modern avantgardist hero or a hopelessly unrepentant White Male Colonialist are lined up here, and the endnotes alone may serve as a reliable compass for entering the jungle of Gauguin's life and work. Another especially readable piece is Allison Perelman's "The Burning Yellow Atelier" (pp.64-72) which provides a much needed account of the strange and wild chapter of the artists's 
life back in Paris from January 1894 to June 1895, between his two Polynesian sojourns; it is the story of his meticulously staged studio-cum-exhibition space in rue Vercingetorix, an idiomatic construct between living space and art installation which Perelman aptly calls Gauguin's "visual manifesto". Chrome yellow walls, Tahitian paintings in all the colours of the rainbow, and not least, a flippant entourage starring his 14-year old mistress, Annah la Javanaise and a monkey, set the tone of one of the most outre art spaces before 1900. Such madcap antics bring another Perelman to mind, the humorist S.J. (probably no relation of Ms Perelman here) who wrote for The New Yorker for decades, and his piece in the Nov. 1942 issue, "Beat Me, PostImpressionist Daddy" - a hilarious take on making Gauguin's life (and artists' lives in general) into Holywood movies by blowing up certain saucy details and obscuring others.

In several of the catalogue's (broadly introductory rather than scholarly innovative) texts as well as in the exhibition display, there's more than a hint of a toppling of the balance between 'fine art' and crafts in Gauguin, to the advancement of the latter. A less often used quote dating from 1892 in which Gauguin ponders whether he should in fact have become an "artisan" instead of an "artiste" is brought forward. But this is solidly countermanded by the very artistic appearance and status of his work in general, as well as by his massive ego: "I am a great artist, and I know it."

That characteristically self-assured statement is not let down by this show. After a visit one understands why the story about Gauguin remains a fabulous yarn, a fugue with limitless potential for interpretation. All in all, the Franco-American collaboration is a timely mustering of Gauguin viewed across the entire field of his exploits, and its display of masterworks on loan is impressive. The artist's unfettered ventures into the very borderline areas of sculpture, painting and design are far from exhausted with this exhibition, but you leave it with gold dust in your eyes. Gauguin's dream of the ever undecided motif, the sustained conceptual liability of a given work of art and its' 'meaning' is intact. Even though the miracle of alchemy never materialises, the enigma which he seems to have desired is present. At the same time it is hard not to yearn for that really grand format, which seems to have seeped slowly but inevitably out of art now, 100 years post Gauguin and company. Perhaps it is the taste for magic, which draws the present-day visitor, so a piece of advice: order your ticket online, the queue is as long as the Seine.

Flemming Friborg (b. 1965), MA in Art History, is Associate Professor at the Dept. of Arts and Cultural Studies at the University of Copenhagen, Denmark. Friborg was Director of the Ny Carlsberg Glyptotek 2002-17, and is presently conducting a 3 -year research project on Impressionism, financed by the New Carlsberg Fpundation. The project is further supported through The Carlsberg Foundation's “Semper Ardens” Fellowships within the Humanities and Social Sciences.

\section{References}

1. (1720) Arguably to be exact. See Wootton, David: The Invention of Science (London 2015) pp. 355.

2. Feneon, Felix, Calendrier de decembre. (1988) Vitrines des marchands de tableaux. In: La revue independente, janvier 1888, p. 170ff (My translation). On Gauguin/Feneon, see Joan U. Halperin's magisterial "Felix Feneon. Aesthete \& Anarchist in Fin-de-Siècle Paris, Yale University Press, USA.

3. Merlhes V (1984) Correspondance de Paul Gauguin (Paris 1984), pp. 294-295.

4. (1888) Iconsider this hole of a place to exhibit could do us harm from every point of view. First: after Signac, Dubois-Pillet, it would mean arriving on the scene like a very young newcomer." Gauguin, letter to Schuffenecker, pp. 295-296.

\section{Your next submission with Juniper Publishers will reach you the below assets}

- Quality Editorial service

- Swift Peer Review

- Reprints availability

- E-prints Service

- Manuscript Podcast for convenient understanding

- Global attainment for your research

- Manuscript accessibility in different formats

( Pdf, E-pub, Full Text, Audio)

- Unceasing customer service

Track the below URL for one-step submission https://juniperpublishers.com/online-submission.php 